\title{
Microcystis aeruginosa
}

4 Su Chern Foo ${ }^{\text {ab* }}$, Ian J. Chapman ${ }^{\text {ac }}$, David, M. Hartnell ${ }^{\text {ad }}$, Andrew D. Turner ${ }^{\text {d }}$, Daniel J. Franklin ${ }^{\mathrm{a}}$

$6 \quad{ }^{\mathrm{a}}$ Department of Life \& Environmental Sciences, Faculty of Science \& Technology, Bournemouth University, Talbot 7 Campus, Fern Barrow, Poole, Dorset BH12 5BB, UK.

${ }^{\mathrm{b}}$ School of Science, Monash University Malaysia, Jalan Lagoon Selatan, 47500, Bandar Sunway, Selangor Darul

9 Ehsan, Malaysia.

$10{ }^{\mathrm{c}}$ New South Wales Shellfish Program, NSW Food Authority, Taree, NSW 2430, Australia

$11{ }^{\mathrm{d}}$ Centre for Environment, Fisheries and Aquaculture Science (CEFAS), The Nothe, Barrack Road, Weymouth, 12 Dorset, DT4 8UB, UK.

13 *Corresponding author: suchern@gmail.com 


\section{Abstract}

16 The application of hydrogen peroxide $\left(\mathrm{H}_{2} \mathrm{O}_{2}\right)$ as a management tool to control Microcystis blooms has become 17 increasingly popular due to its short lifetime and targeted action. $\mathrm{H}_{2} \mathrm{O}_{2}$ increases intracellular reactive oxygen 18 species resulting in oxidative stress and subsequently cell death. $\mathrm{H}_{2} \mathrm{O}_{2}$ is naturally produced in freshwater bodies as 19 a result of photocatalytic reactions between dissolved organic carbon and sunlight. Previously, some studies have suggested that this environmental source of $\mathrm{H}_{2} \mathrm{O}_{2}$ selectively targets for toxigenic cyanobacteria strains in the genus

21 Microcystis. Also, past studies only focused on the morphological and biochemical changes of $\mathrm{H}_{2} \mathrm{O}_{2}$-induced cell 22 death in Microcystis with little information available on the effects of different $\mathrm{H}_{2} \mathrm{O}_{2}$ concentrations on growth, esterase activity and membrane integrity. Therefore, this study investigated the effects of non-lethal (40-4000 nM)

24 concentrations on percentage cell death; with a focus on sub-lethal $(50 \mu \mathrm{M})$ and lethal $(275 \mu \mathrm{M} ; 500 \mu \mathrm{M})$ doses of $\mathrm{H}_{2} \mathrm{O}_{2}$ on growth, cells showing esterase activity and membrane integrity. The non-lethal dose experiment was part of a preliminary study. Results showed a general effect of dose and time dependent relationship in all three Microcystis strains post $\mathrm{H}_{2} \mathrm{O}_{2}$ treatment. $\mathrm{H}_{2} \mathrm{O}_{2}$ resulted in a significant increase in intracellular reactive oxygen species, decreased chlorophyll $a$ content, decreased growth rate and esterase activity. Interestingly, at sub-lethal (50 $\mu \mathrm{M}$ $\mathrm{H}_{2} \mathrm{O}_{2}$ treatment), percentage of dead cells in microcystin-producing strains were significantly higher $(\mathrm{p}<0.05)$ from non-microcystin producing strains at $72 \mathrm{~h}$. These findings further cement our understanding of the influence of $\mathrm{H}_{2} \mathrm{O}_{2}$ on different strains of Microcystis and its impact on membrane integrity and metabolic physiology; important to future toxic bloom control programmes.

Keywords: algae bloom; microcystin; hydrogen peroxide; lethal; growth; metabolic activity; cell membrane integrity, flow cytometry 


\section{Introduction}

The toxic cyanobacterial secondary metabolite microcystin, produced by Microcystis sp. and other cyanobacteria represents a threat to drinking water and the use of recreational lakes worldwide (Carmichael \&Boyer 2016, Huisman et al. 2018, O'neil et al. 2012). $\mathrm{H}_{2} \mathrm{O}_{2}$ application is an effective anti-cyanobacterial control method (Matthijs et al. 2012, Wang et al. 2018). $\mathrm{H}_{2} \mathrm{O}_{2}$ has a short life span of $4 \mathrm{~h}$ to $20 \mathrm{~h}$ in water bodies (Cooper et al. 1994) and is selectively toxic towards cyanobacteria compared to other phytoplankton taxa and aquatic invertebrates (Jančula et al. 2008). Several studies have reported $\mathrm{H}_{2} \mathrm{O}_{2}$ concentrations with a lethal effect on Microcystis cells (Drábková et al. 2007a, Dziallas \&Grossart 2011, Matthijs et al. 2012) at concentrations ranging from $118 \mu \mathrm{M}$ (Mikula et al. 2012) to $325 \mu \mathrm{M}$ (Ding et al. 2012) with the potency of the $\mathrm{H}_{2} \mathrm{O}_{2}$ effect varying with light intensity (e.g. (Drábková et al. 2007a)). There is limited information on the variability of $\mathrm{H}_{2} \mathrm{O}_{2}$ sensitivity across Microcystis strains, and how this is linked with culture history. Recently, there has been great interest in the role of intracellular microcystin concentration in modulating sensitivity to oxidative stress measured by $\mathrm{H}_{2} \mathrm{O}_{2}$ degradation and transcriptome analysis (Schuurmans et al. 2018). Therefore, further testing on the Microcystis cellular response to $\mathrm{H}_{2} \mathrm{O}_{2}$ were conducted in this study using metabolic probes.

Production of reactive oxygen species (ROS) within photosynthetic cells is an ecologically relevant and natural phenomenon. Types of reactive oxygen species include superoxide anion $\left(\mathrm{O}_{2}{ }^{-}\right)$, reactive hydroxyl radicals $(\mathrm{OH})$ as well as $\mathrm{H}_{2} \mathrm{O}_{2}$. The concentration of environmental $\mathrm{H}_{2} \mathrm{O}_{2}$ in lakes range from 0.03 to $1.04 \mu \mathrm{M}$ (Cooper \&Lean 1989, Häkkinen et al. 2004). These concentrations elevate when UV irradiation photo-catalyzes dissolved organic carbon in both surface and groundwater (Cooper \&Zika 1983); releasing superoxide $\left(\mathrm{O}_{2}{ }^{\prime-}\right)$ and $\mathrm{H}_{2} \mathrm{O}_{2}$ (Paerl \&Otten 2013). ROS stress is exacerbated when exogenous $\mathrm{H}_{2} \mathrm{O}_{2}$ generation leads to a mismatch between oxidant concentration and cellular antioxidant capacity (Bouchard \&Purdie 2011). Cellular damage linked to ROS stress in cyanobacteria includes suppression of de novo protein synthesis (Nishiyama et al. 2004), thylakoid membrane damage (Drábková et al. 2007b), inhibition of transcription of photosynthesis-related genes (i.e. psaB, psbD1, rbcL) (Qian et al. 2010) and finally DNA strand breakage (He \&Häder 2002). In addition to these impacts, it has been observed that $\mathrm{H}_{2} \mathrm{O}_{2}$ treatment results in a higher induction of cellular lipid peroxidation in cyanobacteria compared to green microalgae (Leunert et al. 2014). 
Microcystin is produced non-ribosomally via a multifunctional enzyme complex (peptide synthetase and polyketide synthetase modules) as coded by the mcy gene cluster (Yamaguchi et al. 2020). Interestingly, there are two opposing theories. The first theory suggesting that microcystin (mcy)-producing cells have a greater tolerance compared to non-mcy producing strains when subjected to temperature and $\mathrm{H}_{2} \mathrm{O}_{2}$ stress (Dziallas \&Grossart 2011, Zilliges et al. 2011). This selective advantage could be exacerbated by high light illumination (Kaebernick et al. 2000), dissolved organic carbon (Paerl \&Otten 2013) and oxidative stress (Phelan \&Downing 2011). The second theory showed that this was not case where mcy-producing strain did not recover but non $m c y$-producing strain recovered post $\mathrm{H}_{2} \mathrm{O}_{2}$ treatment (Schuurmans et al. 2018). In this work, the relative ability of $m c y$-producing Microcystis cells (PCC7806; CCAP 1450/17) and non-mcy producing cells (PCC 7806-mcyB) to cope with $\mathrm{H}_{2} \mathrm{O}_{2}$ stress was evaluated. The objective of this study was to compare the effects of sublethal (50 $\mu \mathrm{M})$ and lethal $(275 \mu \mathrm{M}$ and $500 \mu \mathrm{M})$ concentrations of $\mathrm{H}_{2} \mathrm{O}_{2}$ at constant light levels of $110 \mu \mathrm{mol}$ photons $\mathrm{m}^{-2} \mathrm{~s}^{-1}$ on Microcystis physiology. Measures of $\mathrm{H}_{2} \mathrm{O}_{2}$ effects included intracellular reactive oxygen species accumulation, growth rates, chlorophyll $a$ content, percentage cells showing esterase activity and dead cells.

\section{Materials and methods}

\section{Microcystis aeruginosa strains and culture conditions}

Three Microcystis strains: PCC 7806 and PCC7806-mcyB (location and year of isolation: Braakman water reservoir, The Netherlands; 1972) and CCAP 1450/17 (Ivy Lake, UK; 2014) were pre-cultivated in an AlgaeTron AG230 incubator (PSI, Czech Republic). The $m c y B$ gene-deficient, PCC7806-mcyB strain was produced by insertional mutagenesis of a chloramphenicol resistance gene cassette and maintained at $5 \mu \mathrm{g} / \mathrm{mL}$ chloramphenicol (Dittmann et al. 1997). Inoculation density was $2 \times 10^{6}$ cells $/ \mathrm{mL}$ in $250 \mathrm{~mL}$ of BG11 (Stanier et al. 1971) in $500 \mathrm{~mL}$ Erlenmeyer flasks at $32.9 \pm 1.6{ }^{\circ} \mathrm{C}$ and light levels of $110 \mu \mathrm{mol}$ photons $\mathrm{m}^{-2} \mathrm{~s}^{-1}$ (Biospherical Instrument Inc., PAR Scalar Irradiance sensor, San Diego, CA, United States) at a 12:12 L:D (light: dark) cycle for 5 days to obtain cells at mid-exponential phase.

\section{Toxin characterization}

Cultures were sampled bi-weekly in early to late exponential growth phase, three aliquots of $250 \mu \mathrm{L}$ were taken and filtered using $25 \mathrm{~mm} 1.2 \mu \mathrm{m}$ filters (Whatman, GF/C). Filter papers were preserved at $-80{ }^{\circ} \mathrm{C}$. On analysis, filters were allowed to thaw to room temperature and immersed in $10 \mathrm{~mL}$ of $80 \%$ methanol and $20 \%$ ultra- 
pure $\mathrm{H}_{2} \mathrm{O}(80 / 20 \mathrm{v} / \mathrm{v})$, shaken on a high-speed rotary shaker for 5 mins and left for $1 \mathrm{~h}$ at ambient temperature. Measurements of microcystins were divided by cell counts to calculate the mass of toxin per cell in femtograms (fg/cell). Toxin analysis was carried out on stock cultures before experiments (but not during $\mathrm{H}_{2} \mathrm{O}_{2}$ exposures) by ultra-high performance liquid chromatography (UHPLC) (Acquity, Waters, Manchester, UK) coupled to a tandem quadruple mass spectrometer (Xevo TQ, Waters, Manchester, UK). All instrument solvents and chemicals were of LC-MS-grade (Fisher Optima, ThermoFisher, Manchester, UK). Reference toxins used for the detection method included the microcystin analogues MC-RR, MC-LA, MC-LY, MC-LF, MC-LW, MC-YR, MC-WR, MC-HilR, MC-HtyR, MC-LR \& Asp3-MC-LR (Enzo Life Sciences, Exeter, UK) and [Dha $\left.{ }^{7}\right]-M C-L R$ and matrix reference material of blue-green algae (RM-BGA, Lot 201301) containing a range of microcystins (Institute of Biotoxin Metrology, National Research Council Canada). Analysis of microcystins was conducted following the method by Turner et al. (2018). Microcystins were chromatographically separated using a $1.7 \mu \mathrm{m}, 2.1 \times 50 \mathrm{~mm}$ Waters Acquity BEH C18 column, held at $+60{ }^{\circ} \mathrm{C}$, with mobile phase of $\mathrm{H}_{2} \mathrm{O}+0.025 \%$ formic acid (A) and acetonitrile $+0.025 \%$ formic acid (B). The UHPLC gradient schedule was: $2 \% \mathrm{~B}$ initial conditions rising to $25 \% \mathrm{~B}$ at 0.5 min holding until 1.5 mins, rising to $40 \% \mathrm{~B}$ at $3.0 \mathrm{mins}$, increasing further to $50 \% \mathrm{~B}$ at 4 mins, a quick rise to $95 \% \mathrm{~B}$ at $4.1 \mathrm{mins}$ and held until 4.5 mins until dropping back to $2 \% \mathrm{~B}$ at 5 mins. The total run time was 5.5 mins.

The Waters Xevo TQ tune parameters were as follows: $150{ }^{\circ} \mathrm{C}$ source temperature, $600{ }^{\circ} \mathrm{C}$ desolvation temperature, $600 \mathrm{~L} / \mathrm{h}$ desolvation gas flow, $0.15 \mathrm{~mL} / \mathrm{min}$ collision gas flow. Capillary voltage was held at $1.0 \mathrm{kV}$. Selected Reaction Monitoring (SRM) transitions were built into the MS/MS method using positive mode acquisition for each toxin. Parent and daughter ions, as well as cone and collision voltages were optimized following experiments infusing pure standards into the mass spectrometer in the mobile phase. Most microcystins exhibited unique SRM transitions and chromatographic retention times, resulting in good separation over the 5.5 mins run time. The exception was $\left[\mathrm{Dha}^{7}\right]-\mathrm{MC}-\mathrm{LR}$ and Asp3-MC-LR, which shared the same transitions and could not be completely resolved. These two microcystins are therefore reported together. This method has been previously validated for the quantification of microcystins in water and algae and is accredited to ISO17025 standard (Turner et al. 2018). 


\section{Selection of $\mathrm{H}_{2} \mathrm{O}_{2}$ treatments}

The determination of suitable $\mathrm{H}_{2} \mathrm{O}_{2}$ dosages was investigated in preliminary experiments. Concentrations of $\mathrm{H}_{2} \mathrm{O}_{2}(40 \mathrm{nM}, 400 \mathrm{nM}$ and $4000 \mathrm{nM})$ caused no, or only a very small, difference to the number of dead cells within the population as assessed by SYTOX-green staining (Table 1). Subsequently, $50 \mu \mathrm{M}, 275 \mu \mathrm{M}$ and $500 \mu \mathrm{M}$ concentrations were selected to encompass a range of sub-lethal and lethal population doses to the three investigated Microcystis strains.

\section{$\mathrm{H}_{2} \mathrm{O}_{2}$ exposure: physiological assessment}

After pre-cultivation, triplicate cultures were diluted with fresh BG11 media to obtain $100 \mathrm{~mL}$ of experimental cell suspensions at an initial cell density of $1 \times 10^{6}$ cells $/ \mathrm{mL}$ in $250 \mathrm{~mL}$ Erlenmeyer flasks. The strains, along with no $\mathrm{H}_{2} \mathrm{O}_{2}$ controls, were incubated for three days with a daily addition of $\mathrm{H}_{2} \mathrm{O}_{2}(50 \mu \mathrm{M}, 275 \mu \mathrm{M}, 500 \mu \mathrm{M})$ during the middle of the light phase. Cultures were gently agitated once per day. Cells were left to incubate for 60 mins after the addition of $\mathrm{H}_{2} \mathrm{O}_{2}(30 \%$ w/w, Sigma-Aldrich, cat. no. H1009, St. Louis, USA). After that, samples from each Microcystis culture were analyzed on a benchtop Accuri C6 flow cytometer (BD Biosciences, San Jose, California) in order to examine cell esterase activity (CM-FDA staining), membrane integrity (SYTOX ${ }^{\circledR}$ Green staining) and intracellular reactive oxygen species content $\left(\mathrm{CM}-\mathrm{H}_{2} \mathrm{DCFDA}\right.$ staining). The influence of different $\mathrm{H}_{2} \mathrm{O}_{2}$ concentrations on Microcystis cell membrane and physiology was monitored every 24 h for 3 days. The water samples were collected $3 \mathrm{~h}$ after initial light cycle started.

\section{Cell counts with BD accuri C6 flow cytometry and chlorophyll a extractions}

Total Microcystis cells were counted every $24 \mathrm{~h}$ for 3 days. The effect of $\mathrm{H}_{2} \mathrm{O}_{2}$ on cell growth was evaluated by measuring forward scattering properties (FSC) and phycocyanin (FL4: 675 $\pm 12.5 \mathrm{~nm}$; far red) florescence using flow cytometry. Cytometer run settings were 2 mins, $10 \mu \mathrm{L}$ core size, $14 \mu \mathrm{L} / \mathrm{min}$ flow rate and threshold set at 10,000 on FSC signal following a previous method (Hartnell et al. 2016). Histograms of cell populations were plotted (counts vs. FSC) and number of cells calculated. Each $\mathrm{H}_{2} \mathrm{O}_{2}$ treatment was run in triplicate $(\mathrm{n}=3)$. M. aeruginosa cells were distinguished by gating the highest histogram peak found in the far red channel representing cells with non-degraded phycocyanin fluorescence (FL4-H: excitation $640 \mathrm{~nm}$ : emission $675 \pm 12.5 \mathrm{~nm}$ ) into a FSC-H histogram plot representing cell size. The FSC-H peak was then gated in a density plot of both FSC-H and SSC-H to determine the final count. Besides that, the chlorophyll a content of Microcystis cells was measured on the first and last day of the 
141

142

143

experiment. This was done by extracting chl $a$ in $100 \%$ methanol for $4 \mathrm{~h}$ and absorbance readings taken using a UVVIS spectrophotometer at $665.2 \mathrm{~nm}, 652.4 \mathrm{~nm}$ and $470 \mathrm{~nm}$ (Wellburn 1994). Pigment results were expressed in $\mu \mathrm{g}$ chl $a / \mathrm{mL}$.

\section{CM- ${ }_{2}$ DCFDA (ROS) labelling}

Intracellular reactive oxygen species (ROS) in Microcystis cells were detected via staining with chloromethyl 2',7'-dichlorodihydrofluorescein diacetate (CM-H2DCFDA; Life Technologies, cat. no, C6827, Oregon, USA). CM- $\mathrm{H}_{2}$ DCFDA is hydrolysed by nonspecific esterases which releases 2', 7'-dichlorodihydrofluorescein $\left(\mathrm{CM}-\mathrm{H}_{2} \mathrm{DCF}\right)$. This is further oxidized by intracellular ROS (e.g. $\mathrm{H}_{2} \mathrm{O}_{2}$ ) to CM-DCF (which emits green fluorescence) (Eruslanov \&Kusmartsev 2010). A modified cell staining protocol was followed (Peperzak \&Brussaard 2011). A stock solution was prepared by adding $100 \mu \mathrm{L}$ of ethanol to a tube containing $50 \mu \mathrm{CM}$ $\mathrm{H}_{2} \mathrm{DCFDA}$ to yield the working stock of $0.86 \mu \mathrm{M}$. Following this, $5.2 \mu \mathrm{L}$ from the working stock was added to $180 \mu \mathrm{L}$ of sample in the flow cytometric tube to yield a final concentration of $20 \mathrm{nM}$ which was left to incubate for 60 mins. The green probe fluorescence (FL1) was measured at $533 \pm 15 \mathrm{~nm}$.

\section{CMFDA (esterase) labelling}

Esterase activity of Microcystis sp. was assessed by flow cytometry using fluorescein diacetate (CM-FDA) (Invitrogen, cat. no. S925, Life Technologies, Grand Island, NY, USA) with some modification from a previous method (Mikula et al. 2012). The non-fluorescent FDA substrate is rapidly taken up by cells, where it is hydrolysed intracellularly through cleavage by cellular esterase to give a green-fluorescent substance fluorescein. This fluorescence reflects general hydrolytic enzyme activity which is generally used as a proxy for cell viability (Geary et al. 1998). Before measurement, a stock solution was diluted to yield a $100 \mu \mathrm{M}$ working solution. Five $\mu \mathrm{L}$ of working solution was added to flow cytometry tube containing $1 \mathrm{~mL}$ of sample to yield a final concentration of $0.5 \mu \mathrm{M}$ and incubated for 30 mins. Stained cells were analysed with flow cytometry and Microcystis cells were distinguished by gating on dot plots of forward scatter (FSC, indicating cell size).

\section{SYTOX Green (cell membrane integrity) labelling}

Dead Microcystis cells were identified and enumerated by flow cytometry using SYTOX ${ }^{\circledR}$ Green following a previously published method (Chapman et al. 2016). SYTOX ${ }^{\circledR}$ Green is a membrane-impermeable fluorescent dye. It is only when cell membrane integrity has been lost (during cell death) that SYTOX green crosses the cell membrane and binds to nucleic acids. A stock solution of $5 \mathrm{mM}$ SYTOX Green in DMSO (Invitrogen, catalogue 
number S7020, Life Technologies, Grand Island, NY, USA) was diluted to a working solution of $100 \mu \mathrm{M}$ with ultrapure filtered $\mathrm{H}_{2} \mathrm{O}$. For measurement, $5 \mu \mathrm{L}$ of working solution was added to $1 \mathrm{~mL}$ of sample to obtain a final $\mathrm{SYTOX}^{\circledR}$ concentration of $0.5 \mu \mathrm{M}$. Samples were left to incubate for $30 \mathrm{mins}$ in the dark at room temperature. The green probe fluorescence (FL1) was measured at $533 \pm 15 \mathrm{~nm}$. Cytographs (FL4 vs FL1) were plotted to show percentage of SYTOX+ cells.

\section{Statistical analysis}

Data were processed with SPSS software Version 23 (SPSS Inc, Chicago, USA). After normality testing $(p>0.05)$, a factorial ANOVA was used to test for differences between treatments. To observe differences within treatments at $p<0.05$, a one-way ANOVA and Tukey HSD post hoc test was applied. Pearson correlation was employed to observe significant relationships $(p<0.05)$ between the investigated parameters. Values were given as means \pm standard deviation (SD) of three replicates. Values were considered statistically significant when $p<0.05$.

\section{Results}

\section{Toxin content of Microcystis strains}

Microcystis strains PCC 7806 and CCAP 1450/17 both contained MC-LR and [Dha ${ }^{7}$-MC-LR/Asp3MC-LR, ranging in total microcystins from 21.95 to $31.90 \mathrm{fg} / \mathrm{cell}$ for PCC 7806 and 22.70 to $41.50 \mathrm{fg} / \mathrm{cell} \mathrm{for}$ CCAP 1450/17. Strain PCC 7806- $m c y B$ was negative for all microcystins tested (Table 2).

\section{Effects of $\mathrm{H}_{2} \mathrm{O}_{2}$ on cell growth and chlorophyll a concentration}

In untreated (no $\left.\mathrm{H}_{2} \mathrm{O}_{2}\right)$ PCC 7806-mcyB cultures mean cell number increased from $1.63 \times 10^{6}$ to $8.83 \times 10^{6}$ cells $/ \mathrm{mL}$ over the experimental period with a growth rate of $0.57 \mu / \mathrm{d}$. Meanwhile, mean culture chlorophyll $a$ content significantly increased from 0.17 to $0.97 \mu \mathrm{g}$ chl $a / \mathrm{mL}$. Untreated PCC 7806 cultures increased to a mean of $6.46 \times 10^{6}$ cells $/ \mathrm{mL}$ and $0.89 \mu \mathrm{g} / \mathrm{mL}$ with a growth rate of $0.32 \mu / \mathrm{d}$. Untreated CCAP $1450 / 17 \mathrm{increased}$ to a mean of $3.59 \times 10^{6}$ cells $/ \mathrm{mL}, 0.59 \mu \mathrm{g} \mathrm{chl} \mathrm{a} / \mathrm{mL}$ with a growth rate of $0.28 \mu / \mathrm{d}$ (Figure 1 ).

Moreover at $50 \mu \mathrm{M} \mathrm{H}_{2} \mathrm{O}_{2}$ treatment, the non-mcy producing strain (PCC 7806-mcyB) demonstrated an increase in number of cells from $24 \mathrm{~h}$ to $72 \mathrm{~h}$ by $3.46 \times 10^{6}$ cells. This was followed by the mcy-producing strain PCC7806 with a smaller increase of $1.15 \times 10^{6}$ cells and $1.50 \times 10^{5}$ for CCAP1450/17 strain. Parallel to cell numbers, post $50 \mu \mathrm{M} \mathrm{H}_{2} \mathrm{O}_{2}$ treatment, chlorophyll $a$ content showed a similar pattern where PCC 7806-mcyB strain 
increased to $0.80 \pm 0.04 \mu \mathrm{g} / \mathrm{mL}$ at $72 \mathrm{~h}$ and followed by $m c y$-producing PCC7806 strain $(0.76 \pm 0.03 \mu \mathrm{g} / \mathrm{mL})$. The CCAP1450/17 $(0.54 \pm 0.01 \mu \mathrm{g} / \mathrm{mL})$ strain showed the least increase in chlorophyll $a$ content. (Figure 1).

\section{Effects of $\mathrm{H}_{2} \mathrm{O}_{2}$ on intracellular reactive oxygen species (ROS labelling)}

Increasing lethal doses of $\mathrm{H}_{2} \mathrm{O}_{2}$ treatment $(275 \mu \mathrm{M}, 500 \mu \mathrm{M})$ led to a gradual production of intracellular reactive oxygen species (\% ROS) (Figure 2). This contrasts with the decrease of \% ROS with time in untreated cells. When compared to PCC 7806- $m c y B$ or PCC 7806, CCAP $1450 / 17$ started responding to $\mathrm{H}_{2} \mathrm{O}_{2}$ treatment at $50 \mu \mathrm{M}$ as reflected by the upward trend of $\% \operatorname{ROS}(36.12 \% \rightarrow 46.67 \% \rightarrow 57.45 \% \rightarrow 63.13 \%)$; at a time dependent manner. Instead, the increase in \% ROS in PCC 7806-mcyB and PCC 7806 was only observed in treatment at higher doses of $275 \mu \mathrm{M}$ and $500 \mu \mathrm{M}$; when compared to the respective starting time.

\section{Effects of $\mathrm{H}_{2} \mathrm{O}_{2}$ on esterase activity (CMFDA labelling)}

A general trend was observed where increasing $\mathrm{H}_{2} \mathrm{O}_{2}$ treatment in cells resulted in decreasing esterase activity. Furthermore at $50 \mu \mathrm{m} \mathrm{H}_{2} \mathrm{O}_{2}$ treatment, the non-mcy producing strain (PCC7806-mcyB) demonstrated an increase in esterase activity from $24 \mathrm{~h}$ to $72 \mathrm{~h}$ by $38.36 \%$. This was followed by PCC7806 with a smaller increase of $17.59 \%$ (Figure 3). Unlike the other two strains, the CCAP1450/17 mcy-producing strain demonstrated the opposite with a decrease in esterase activity from $23.60 \pm 14.81 \%(24 \mathrm{~h})$ to $10.32 \pm 5.25 \%$ (72h). The pH of each Microcystis culture during the 3-day experimental study was within the dye's physiological range.

\section{Cell membrane integrity (SYTOX-Green labelling)}

Untreated cells in PCC 7806-mcyB (22.47\%), CCAP 1450/17 (29.72\%) and PCC $7806(25.83 \%)$ had lowest population of dead cells by the end of the experiment compared to respective treated cells (Figure 4). For example, the dead cell population of treated cells at lethal doses $(275 \mu \mathrm{M}$ and $500 \mu \mathrm{M})$ resulted in a peak $(82.56 \%$ $86.32 \%)$ at $24 \mathrm{~h}$ and plateaued $(71.91 \%-82.14 \%)$. This pattern was similar in all treated strains.

In relation to previous discussion of sub-lethal $50 \mu \mathrm{M}$ treatment, percentage cells stained with Sytox green in CCAP1450/17 strain were increasing in a time-dependent manner. This was observed from $48^{\text {th }}$ to $72^{\text {nd }}$ hour where percentage dead cells in CCAP $1450 / 17$ continued to increase to $56.17 \pm 0.11 \%$. This was significantly higher ( $\mathrm{p}<0.05)$ compared to PCC7806 (48.05 $\pm 6.1 \%)$ and PCC7806-mcy $(21.38 \pm 1.63 \%)$. 


\section{Discussion}

\section{Toxin content of Microcystis strains}

Recorded total microcystins cellular quota for PCC7806 strain in this study differed slightly from those of previous studies reporting a maximum of $3 \mathrm{fg} / \mathrm{cell}$ at low light treatments (Phelan \&Downing 2011) or $40 \mathrm{fg} / \mathrm{cell}$ at $13 \pm 3 \mu$ moles photons $\mathrm{m}^{-2} \mathrm{~s}^{-1}$ (Schuurmans et al. 2018). They also differed slightly from Wiedner et al. (2003) who reported a range of 40 to $80 \mathrm{fg} / \mathrm{cell}$ across their light treatments $\left(10-403 \mu \mathrm{mol}\right.$ photons $\left.\mathrm{m}^{-2} \mathrm{~s}^{-1}\right)$. These differences are likely to be attributed to the methods of light intensities, cell counting and toxin quantification, for example Phelan \& Downing (2011) used optical density as a measure of cell abundance and microcystins were quantified by ELISA. Whereas, Wiedner et al. (2003) used a CASY 1 TTC cell analyser system to measure cell density and microcystins were quantified by High-Performance Liquid Chromatography coupled to Time-Of-Fight Mass Spectrometry, with neither approach using ISO-accredited methods. The microcystin analysis conducted here was fully validated and accredited to ISO17025 quality standard, and whilst not used throughout the experimental exposures, did indicate clear differences in microcystin content between strains at the outset of the experiments.

\section{Effects of $\mathrm{H}_{2} \mathrm{O}_{2}$ on cell growth and chlorophyll a concentration}

Overall, our data were supported by a previous study where high doses of $\mathrm{H}_{2} \mathrm{O}_{2}(250 \mathrm{uM}$ and $325 \mathrm{uM})$ in Microcystis strain FACHB-905 resulted in a significant decrease in cell growth (Ding et al. 2012; Mikula et al. 2012). Despite the general trend in the effects of $\mathrm{H}_{2} \mathrm{O}_{2}$, some differences were evident in the species. By $72 \mathrm{~h}$, the $m c y$-producing CCAP1450/17 experienced the biggest drop in cell number at $50 \mathrm{uM} \mathrm{H}_{2} \mathrm{O}_{2}$ treatment to reach $1.23 \times 10^{6} \pm 1.50 \times 10^{5}$ cells. Similarly, PCC7806 cell number dropped to $3.62 \times 10^{6} \pm 2.49 \times 10^{5}$ cells whereas the non- $m c y$ producing strain (PCC7806-mcyB) experienced the lowest drop in cell numbers after $50 \mathrm{uM}_{2} \mathrm{H}_{2}$ treatment to reach $5.35 \times 10^{6} \pm 3.46 \times 10^{6}$ cells. This shows that at sub-lethal $\mathrm{H}_{2} \mathrm{O}_{2}$ concentration, $m c y$-producing strains were more negatively affected than the non-mcy producing strain.

\section{Effects of $\mathrm{H}_{2} \mathrm{O}_{2}$ on intracellular reactive oxygen species (ROS)}

The data from this study show a direct relationship between $\mathrm{H}_{2} \mathrm{O}_{2}$ treatment and ROS accumulation in Microcystis cells. The 2'7'-dichlorofluorescein probe is a commonly used to effectively quantify ROS levels (LeBel et al. 1992). It is also sensitive and can be detected at Pico mole levels (Cathcart et al. 1983). To date, there are still limited studies on the quantification of intracellular ROS in Microcystis strains; except for a study by Bouchard \& Purdie (2011) who employed the use of another fluorescence dihydrorhodamine (DHR) probe. 
Peroxiredoxins are redox-sensitive proteins with thiol groups of cysteines and play an important role as antioxidant enzymes to maintain oxidative balance, especially in cyanobacteria (Allahverdiyeva et al. 2015, Asada 1999, Helman et al. 2005). The presence of $m c y$ gene interferes with peroxiredoxins by binding to the thiol group thereby blocking $\mathrm{H}_{2} \mathrm{O}_{2}$ degradation (Schuurmans et al. 2018). During excess exogenous $\mathrm{H}_{2} \mathrm{O}_{2}$ treatment, the reactive oxygen species crosses the Microcystis cell membrane via diffusion and aquaporin homologue channels (Bienert et al. 2006). The sudden overload of $\mathrm{H}_{2} \mathrm{O}_{2}$ overwhelms the antioxidant balance of the cell, as reflected by the rise in intracellular reactive oxygen species in the ROS assay. Consequently, significant losses of chlorophyll $a$ content was observed in the three investigated strains. It seems that with increasing percentage dead cells in cultures, degradation of $\mathrm{H}_{2} \mathrm{O}_{2}$ by these antioxidant enzymes could not keep up with daily dosage of exogenous $\mathrm{H}_{2} \mathrm{O}_{2}$, causing an oxidative-stressed environment in the cells. This may have led to the disintegration of thylakoids as reflected by decreased chlorophyll $a$ content in the experiment. Past results reported that oxidative stress result in breakdown of light harvesting complexes and inhibition of pigment synthesis (Latifi et al. 2009, Qian et al. 2010). Similarly, this study observed a significant decline in chlorophyll $a$ content with increasing dosage and incubation time. microcystin in cells allows a greater resilience of chlorophyll $a$ against $\mathrm{H}_{2} \mathrm{O}_{2}$ degradation during oxidative stress. However, an important methodological distinction between these two studies is $\mathrm{H}_{2} \mathrm{O}_{2}$ concentration. Dziallas \& Grossart (2011) opted for $25 \mathrm{nM}, 50 \mathrm{nM}$ and $100 \mathrm{nM}$ whilst this study selected higher $\mathrm{H}_{2} \mathrm{O}_{2}$ treatments of $50 \mu \mathrm{M}$, $275 \mu \mathrm{M}$ and $500 \mu \mathrm{M}$. Another contributing factor to the differences between these two studies could be related to the manner of chlorophyll quantification. Both studies used $100 \%$ methanol to extract chlorophyll $a$ and a conventional spectrophotometric method. This may have been insufficiently sensitive as a quantification tool to detect very small changes in chlorophyll $a$. In order to more accurately quantify the effects of ROS degradation of photopigments in Microcystis, and the interaction of this process with viability, high performance liquid chromatography (HPLC) would be a better analytical approach. Overall, this study shows the sub-lethal $50 \mu \mathrm{m} \mathrm{H}_{2} \mathrm{O}_{2}$

272 a higher extent of response than the non-mcy producing strain (PCC7806-mcyB). This was reflected by 273 CCAP1450/17 having the smallest increase in cell number, chl $a$ content, esterase activity and the highest dead cell 274 population. This was followed by the PCC7806 strain having a moderate increase in cell number, chl $a$ content, esterase activity and the second highest dead cell population. Finally, the non-mcy producing strain (PCC7806- 
$m c y B)$ at $50 \mu \mathrm{m} \mathrm{H}_{2} \mathrm{O}_{2}$ treatment responded with an increase in cell number, chl $a$ content, esterase actiivty and the least dead cell population of $21.38 \pm 1.63 \%$ at $72 \mathrm{~h}$.

\section{Effects of $\mathrm{H}_{2} \mathrm{O}_{2}$ on esterase activity}

It was observed in this study that $\mathrm{H}_{2} \mathrm{O}_{2}$ influenced both microcystin and non-microcystin producing strains. In fact, the $m c y$-producing strains (CCAP1450/17 and PCC7806) experienced significant changes $(\mathrm{p}<0.05)$ in their final esterase activity at $72 \mathrm{~h}$ as compared to the non-mcy producing strain (PCC7806-mcyB) at $50 \mu \mathrm{m} \mathrm{H}_{2} \mathrm{O}_{2}$ treatment. At the same time, an increase in percentage dead cells was observed. This can largely be due to cell lysis where loss in membrane integrity and subsequent leakage from cell result in lower fluorescent signals. During cell lysis, intracellular enzymes like caspase, peroxidase and hydrolase are released from dead cell compartments; triggered by lytic enzyme, beta-cyclocitral (Arii et al. 2015). This hypothesis was supported by the increasing dead cell population peaking at $86.32 \%$ in PCC 7806 and $83.49 \%$ in CCAP $1450 / 17$ at $24 \mathrm{~h}$.

The use of CMFDA in M. aeruginosa is common to explain metabolic activity in the cells (Regel et al. 2002). Esterases are positively correlated with cell growth because the rate of FDA conversion to fluorescein is correlated with photosynthesis. It was further supported that metabolic activity and induced chlorophyll $a$ fluorescence are one of the most sensitive biomarkers of exposure of cyanobacteria to $\mathrm{H}_{2} \mathrm{O}_{2}$ (Mikula et al. 2012).

\section{Cell membrane integrity}

Besides the use of CMFDA, SYTOX ${ }^{\circledR}$ green is an unsymmetrical cyanine dye with 4 positive charges and has allowed scientists to rather accurately distinguish between dead and live populations (Roth et al. 1997). Live eukaryotic and prokaryotic cells completely exclude the dye from the cell. However, if cell membrane integrity was compromised, the dye could enter and stain its nucleic acid. This study is one of the first to report membrane integrity changes after $\mathrm{H}_{2} \mathrm{O}_{2}$ treatments in three Microcystis strains.

As pointed out in previous sections, strain CCAP 1450/17 reacted differently at sub lethal dose of $50 \mu \mathrm{M}$ $\mathrm{H}_{2} \mathrm{O}_{2}$ treatment compared to the other two strains. This strain experienced a gradual increase of intracellular reactive oxygen species, followed by decreased chlorophyll $a$ content, low esterase activity and ultimately accumulation of dead cells, with time. These findings show that $m c y$-producing strain CCAP 1450/17 was sensitive to lower amounts of $\mathrm{H}_{2} \mathrm{O}_{2}$ especially at $50 \mu \mathrm{M} \mathrm{H}_{2} \mathrm{O}_{2}$ and $72 \mathrm{~h}$ treatment. In comparison to PCC 7806 strains which have been maintained in an artificial environment (i.e. laboratory cultures) for at least 4 decades (date of strain isolation: $1^{\text {st }}$ January 1972), CCAP 1450/17 was only recently isolated (year of strain isolation: 2014). It is important 
to note that there is a risk that long term maintenance of microalgae in liquid cultures and increased passage numbers may introduce genetic drift and changes to cell characteristics in a similar way as animal cell lines. For example animal cells at high passage numbers experience changes in morphology, stimuli response and gene expression, as compared to lower passage numbers (Briske-Anderson et al. 1997). Nevertheless, all strains demonstrated a general trend that $\mathrm{H}_{2} \mathrm{O}_{2}$ treatment led to a significant increase in intracellular oxidative stress, decreased chlorophyll $a$ content, decreased cell abundance $(\mathrm{r}=0.706, p<0.05)$, decreased esterase activity ( $\mathrm{r}=0.852$; $p<0.05)$ and increased number of dead cells $(\mathrm{r}=0.849 ; p<0.05)$.

Finally, factorial ANOVA statistical analysis enabled us to check if dependent variables (i.e. cell number,

312 esterase activity, membrane integrity) showed consistent differences between factor levels (i.e. dose, time, strain

313 type). Firstly, the main effect $\mathrm{H}_{2} \mathrm{O}_{2}$ concentration (i.e. $0 \mu \mathrm{M}$ and $50 \mu \mathrm{M}$ ) were significantly different $(p<0.05)$ from

$314275 \mu \mathrm{M}$ and $500 \mu \mathrm{M}$ in each dependent variable investigated. Secondly, the main effect duration of dosage at $72 \mathrm{~h}$

315 were significantly different $(p<0.05)$ from the rest of the time of $\mathrm{H}_{2} \mathrm{O}_{2}$ incubation. From this, results illustrate $\mathrm{H}_{2} \mathrm{O}_{2}$ 316 treatment significantly influences Microcystis population mortality in a dose and time dependent manner. Thirdly, 317 strain type also has a significant effect $(p<0.05)$ on investigated dependent variables. Finally, statistical values 318 showed there is an interaction effect $(p<0.05)$ between factors (dose*time*strain; dose*time; dose*strain; 319 time*strain).

This study uses three Microcystis strains and a combination of modern techniques to provide useful data to one of the most important questions in cyanobacteria ecology currently: whether the predicted increase in 322 cyanobacteria will consist of toxigenic vs non-toxigenic cells due to the way these different types of cells respond to increasing $\mathrm{H}_{2} \mathrm{O}_{2}$ treatment. This is important as the usage rate of $\mathrm{H}_{2} \mathrm{O}_{2}$ to control algae blooms is a very important question for water managers. Overall, the findings in this study support Schuurmans et al. (2018) but does not support a previous theory where presence of $m c y$-gene in strains could confer protection against oxidative stress. Findings from this study showed that $\mathrm{H}_{2} \mathrm{O}_{2}$ treatment of more than $275 \mu \mathrm{M}$ were lethal regardless if it was a $m c y$ or non $m c y$ producing strain. In addition, the sub lethal $50 \mu \mathrm{M} \mathrm{H}_{2} \mathrm{O}_{2}$ treatment could selectively control $m c y$-producing strains resulting in lesser increase in cell number, chl $a$ content, esterase activity and the most percentage dead cell population as observed in the CCAP1450/17 strains. Conversely at the same $50 \mu \mathrm{M} \mathrm{H}_{2} \mathrm{O}_{2}$ treatment, the non $m c y$-producing strain (PCC7806-mcyB) evidenced an increase in cell number, chl $a$ content, esterase activity and the least dead cell population of $21.38 \pm 1.63 \%$ at $72 \mathrm{~h}$. 


\section{Conclusions}

This study shows a dose and time dependent relationship of $\mathrm{H}_{2} \mathrm{O}_{2}$ treatment in all investigated strains, where general effects of $\mathrm{H}_{2} \mathrm{O}_{2}$ treatment were confirmed as observed in the significant increase in intracellular reactive oxygen species, decreased chlorophyll $a$ content, decreased number of cells $(\mathrm{r}=0.706, p<0.05)$, decreased esterase activity $(\mathrm{r}=0.852 ; p<0.05)$ and an increased number of dead cells $(\mathrm{r}=0.849 ; p<0.05)$. Our findings did not support the idea that microcystin-producing cells (PCC7806 or CCAP1450/17) are better at coping with $\mathrm{H}_{2} \mathrm{O}_{2}$ stress than non-toxin producing strain, PCC 7806-mcyB. More so, the $m c y$-producing CCAP 1450/17 strain was found to be sensitive to lower amounts of $\mathrm{H}_{2} \mathrm{O}_{2}$ treatment compared to the two PCC 7806 strains; corroborating Schuurmans et al. (2018)'s findings that presence of $m c y$ gene do not confer protection to cells. This study demonstrates the overall influence of $\mathrm{H}_{2} \mathrm{O}_{2}$ treatment on Microcystis membrane integrity, metabolic physiology, and intracellular reactive oxygen species accumulation; and highlight the factors that can contribute to differences between strains.

\section{Notes}

\section{Acknowledgements}

The authors acknowledge and thank Bournemouth University for financial support during this study and European Union cLINK (Centre of Excellence for learning, innovation, networking and knowledge project) funding (Ref: 372242-1-2012-1-UKERA MUNDUS EMA21).

\section{Authors' contributions}

FSC carried out the experiments, performed the statistical analysis and drafted the manuscript. DF conceived, designed, and critically reviewed the study. AT carried out the toxin characterization studies, and DH collected the data for this section. IC and DH participated in the chlorophyll $a$ content study. All authors read and approved the final manuscript.

\section{Conflict of interest}

The authors declare no conflicts and informed consent. 
Allahverdiyeva Y, Isojärvi J, Zhang P, Aro E-M (2015): Cyanobacterial oxygenic photosynthesis is protected by flavodiiron proteins. Life 5, 716-743

Arii S, Tsuji K, Tomita K, Hasegawa M, Bober B, Harada K (2015): Cyanobacterial blue color formation during lysis under natural conditions. Applied and Environmental Microbiology 81, 2667-2675

Asada K (1999): The water-water cycle in chloroplasts: scavenging of active oxygens and dissipation of excess photons. Annual review of plant biology 50, 601-639

Bouchard JN, Purdie DA (2011): Effect of elevated temperature, darkness, and hydrogen peroxide treatment on oxidative stress and cell death in the bloom-forming toxic cyanobacterium Microcystis aeruginosa. Journal of Phycology 47, 1316-1325

Briske-Anderson MJ, Finley JW, Newman SM (1997): The influence of culture time and passage number on the morphological and physiological development of Caco-2 cells. Proceedings of the society for experimental biology and medicine 214, 248-257

Carmichael WW, Boyer GL (2016): Health impacts from cyanobacteria harmful algae blooms: Implications for the North American Great Lakes. Harmful algae 54, 194-212

Cathcart R, Schwiers E, Ames BN (1983): Detection of picomole levels of hydroperoxides using a fluorescent dichlorofluorescein assay. Analytical Biochemistry 134, 111-116

Chapman IJ, Esteban GF, Franklin DJ (2016): Molecular Probe Optimization to Determine Cell Mortality in a Photosynthetic Organism (Microcystis aeruginosa) Using Flow Cytometry. JoVE (Journal of Visualized Experiments), e53036

Cooper WJ, Zika RG (1983): Photochemical formation of hydrogen peroxide in surface and ground waters exposed to sunlight. Science(Washington) 220, 711-712

Cooper WJ, Lean DRS (1989): Hydrogen peroxide concentration in a northern lake: photochemical formation and diel variability. Environmental science \& technology 23, $1425-1428$

Cooper WJ, Shao C, Lean DRS, Gordon AS, Scully Jr FE (1994): Factors affecting the distribution of $\mathrm{H}_{2} \mathrm{O}_{2}$ in surface waters. Advances in Chemistry Series 237, 391-391

Ding Y, Gan N, Li J, Sedmak B, Song L (2012): Hydrogen peroxide induces apoptotic-like cell death in Microcystis aeruginosa (Chroococcales, Cyanobacteria) in a dose-dependent manner. Phycologia 51, 567-575

Dittmann E, Neilan BA, Erhard M, Von Döhren H, Börner T (1997): Insertional mutagenesis of a peptide synthetase gene that is responsible for hepatotoxin production in the cyanobacterium Microcystis aeruginosa PCC 7806. Molecular microbiology 26, 779-787

Drábková M, Admiraal W, Maršálek B (2007a): Combined exposure to hydrogen peroxide and light selective effects on cyanobacteria, green algae, and diatoms. Environmental science \& technology 41, 309-314

Drábková M, Matthijs HCP, Admiraal W, Maršálek B (2007b): Selective effects of $\mathrm{H}_{2} \mathrm{O}_{2}$ on cyanobacterial photosynthesis. Photosynthetica 45, 363-369

Dziallas C, Grossart H-P (2011): Increasing oxygen radicals and water temperature select for toxic Microcystis sp. PLoS One 6, e25569

Eruslanov E, Kusmartsev S (2010): Identification of ROS using oxidized DCFDA and flowcytometry, Advanced protocols in oxidative stress II. Springer, pp. 57-72

Geary S, Ganf G, Brookes J (1998): The use of FDA and flow cytometry to measure the metabolic activity of the cyanobacteria, Microcystis aeruginosa. SIL Proceedings, 1922$201026,2367-2369$ 
Häkkinen PJ, Anesio AM, Granéli W (2004): Hydrogen peroxide distribution, production, and decay in boreal lakes. Canadian Journal of Fisheries and Aquatic Sciences 61, 1520-1527

Hartnell DM, Chapman IJ, Esteban GF, Franklin DJ (2016): Exploiting eco-physiological niche to facilitate the separation of the freshwater cyanobacteria Microcystis sp. and Synechococcus sp. Journal of microbiological methods 122, 13-15

He Y-Y, Häder D-P (2002): Reactive oxygen species and UV-B: effect on cyanobacteria. Photochemical \& Photobiological Sciences 1, 729-736

Helman Y, Barkan E, Eisenstadt D, Luz B, Kaplan A (2005): Fractionation of the three stable oxygen isotopes by oxygen-producing and oxygen-consuming reactions in photosynthetic organisms. Plant physiology 138, 2292-2298

Huisman J, Codd GA, Paerl HW, Ibelings BW, Verspagen JM, Visser PM (2018): Cyanobacterial blooms. Nature Reviews Microbiology 16, 471-483

Jančula D, Drábková M, Černý J, Karásková M, Koř́ínková R, Rakušan J, Maršálek B (2008): Algicidal activity of phthalocyanines-Screening of 31 compounds. Environmental toxicology 23, 218-223

Kaebernick M, Neilan BA, Borner T, Dittmann E (2000): Light and the transcriptional response of the microcystin biosynthesis gene cluster. Applied and Environmental Microbiology 66, 3387-3392

Latifi A, Ruiz M, Zhang CC (2009): Oxidative stress in cyanobacteria. FEMS microbiology reviews 33, 258-278

LeBel CP, Ischiropoulos H, Bondy SC (1992): Evaluation of the probe 2', 7'-dichlorofluorescin as an indicator of reactive oxygen species formation and oxidative stress. Chemical research in toxicology 5, 227-231

Leunert F, Eckert W, Paul A, Gerhardt V, Grossart H-P (2014): Phytoplankton response to UVgenerated hydrogen peroxide from natural organic matter. Journal of Plankton Research 36, 185-197

Matthijs HCP, Visser PM, Reeze B, Meeuse J, Slot PC, Wijn G, Talens R, Huisman J (2012): Selective suppression of harmful cyanobacteria in an entire lake with hydrogen peroxide. Water research 46, 1460-1472

Mikula P, Zezulka S, Jancula D, Marsalek B (2012): Metabolic activity and membrane integrity changes in Microcystis aeruginosa-new findings on hydrogen peroxide toxicity in cyanobacteria. European Journal of Phycology 47, 195-206

Nishiyama Y, Allakhverdiev SI, Yamamoto H, Hayashi H, Murata N (2004): Singlet oxygen inhibits the repair of photosystem II by suppressing the translation elongation of the D1 protein in Synechocystis sp. PCC 6803. Biochemistry 43, 11321-11330

O'neil J, Davis T, Burford M, Gobler C (2012): The rise of harmful cyanobacteria blooms: the potential roles of eutrophication and climate change. Harmful algae 14, 313-334

Paerl HW, Otten TG (2013): Environmental science. Blooms bite the hand that feeds them. Science (New York, N.Y.) 342, 433-434

Peperzak L, Brussaard CPD (2011): Flow cytometric applicability of fluorescent vitality probes on phytoplankton. Journal of Phycology 47, 692-702

Phelan RR, Downing TG (2011): A growth advantage for microcystin production by Microcystis PCC7806 under high light. Journal of phycology 47, 1241-1246

Qian H, Yu S, Sun Z, Xie X, Liu W, Fu Z (2010): Effects of copper sulfate, hydrogen peroxide and N-phenyl-2-naphthylamine on oxidative stress and the expression of genes involved 
photosynthesis and microcystin disposition in Microcystis aeruginosa. Aquatic Toxicology 99, 405-412

Regel RH, Ferris JM, Ganf GG, Brookes JD (2002): Algal esterase activity as a biomeasure of environmental degradation in a freshwater creek. Aquatic Toxicology 59, 209-223

Roth BL, Poot M, Yue ST, Millard PJ (1997): Bacterial viability and antibiotic susceptibility testing with SYTOX green nucleic acid stain. Applied and Environmental Microbiology $63,2421-2431$

Schuurmans JM, Brinkmann BW, Makower AK, Dittmann E, Huisman J, Matthijs HC (2018): Microcystin interferes with defense against high oxidative stress in harmful cyanobacteria. Harmful algae 78, 47-55

Stanier RY, Kunisawa R, Mandel M, Cohen-Bazire G (1971): Purification and properties of unicellular blue-green algae (order Chroococcales). Bacteriological reviews 35, 171

Turner AD, Waack J, Lewis A, Edwards C, Lawton L (2018): Development and singlelaboratory validation of a UHPLC-MS/MS method for quantitation of microcystins and nodularin in natural water, cyanobacteria, shellfish and algal supplement tablet powders. Journal of Chromatography B 1074, 111-123

Wang J, Chen Z, Chen H, Wen Y (2018): Effect of hydrogen peroxide on Microcystis aeruginosa: Role of cytochromes P450. Science of the Total Environment 626, 211-218

Wellburn AR (1994): The Spectral Determination of Chlorophylls $a$ and $b$, as well as Total Carotenoids, Using Various Solvents with Spectrophotometers of Different Resolution. Journal of Plant Physiology 144, 307-313

Wiedner C, Visser PM, Fastner J, Metcalf JS, Codd GA, Mur LR (2003): Effects of light on the microcystin content of Microcystis strain PCC 7806. Applied and Environmental Microbiology 69, 1475-1481

Yamaguchi H, Suzuki S, Osana Y, Kawachi M (2020): Genomic Characteristics of the Toxic Bloom-Forming Cyanobacterium Microcystis aeruginosa NIES-102. Journal of Genomics 8, 1

Zilliges Y, Kehr J-C, Meissner S, Ishida K, Mikkat S, Hagemann M, Kaplan A, Börner T, Dittmann E (2011): The cyanobacterial hepatotoxin microcystin binds to proteins and increases the fitness of Microcystis under oxidative stress conditions. PloS one 6, e17615 


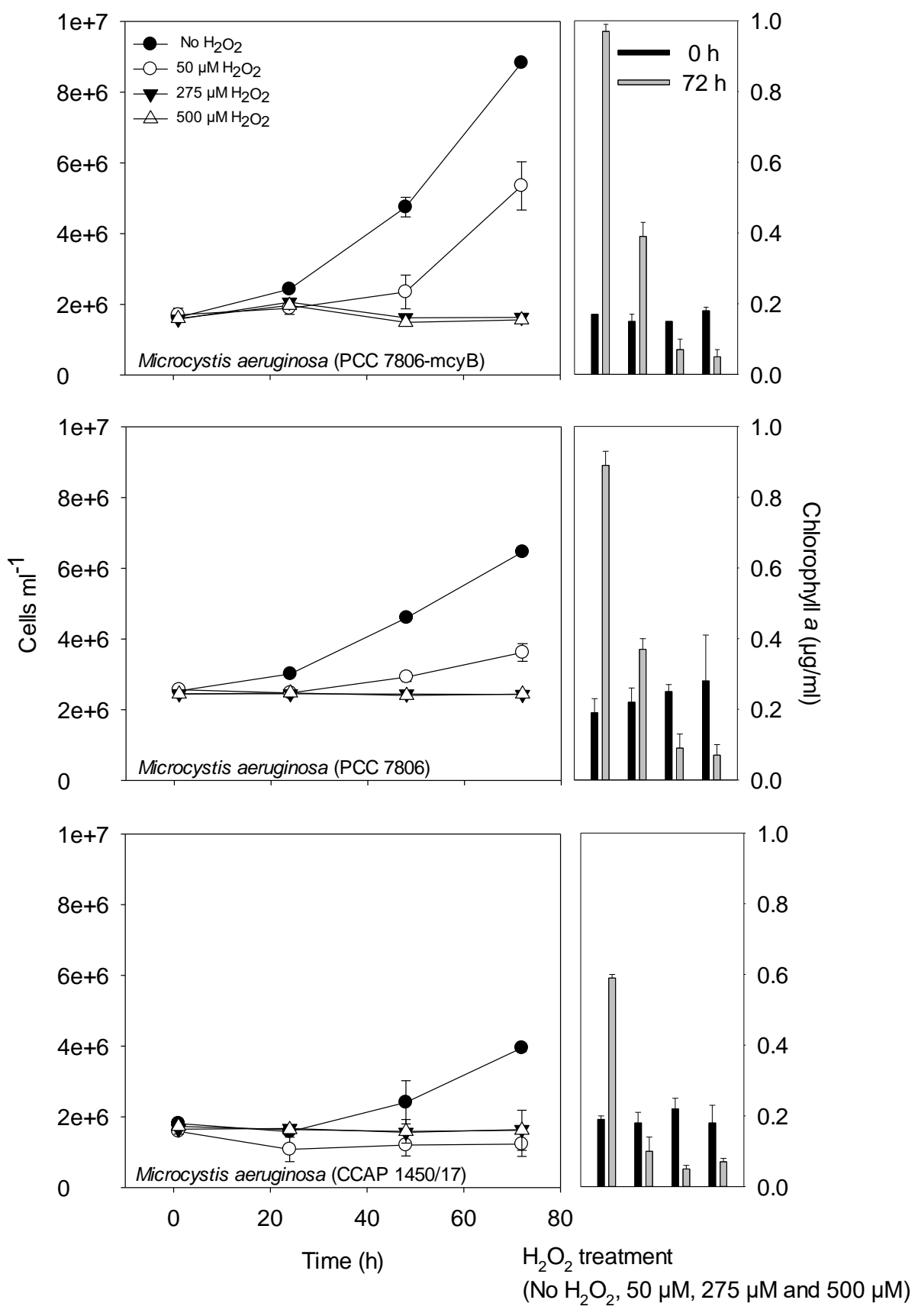

Fig. 1 Cell density and Chlorophyll $a$ levels of three Microcystis sp. treated at an increasing $\mathrm{H}_{2} \mathrm{O}_{2}$ concentration. 

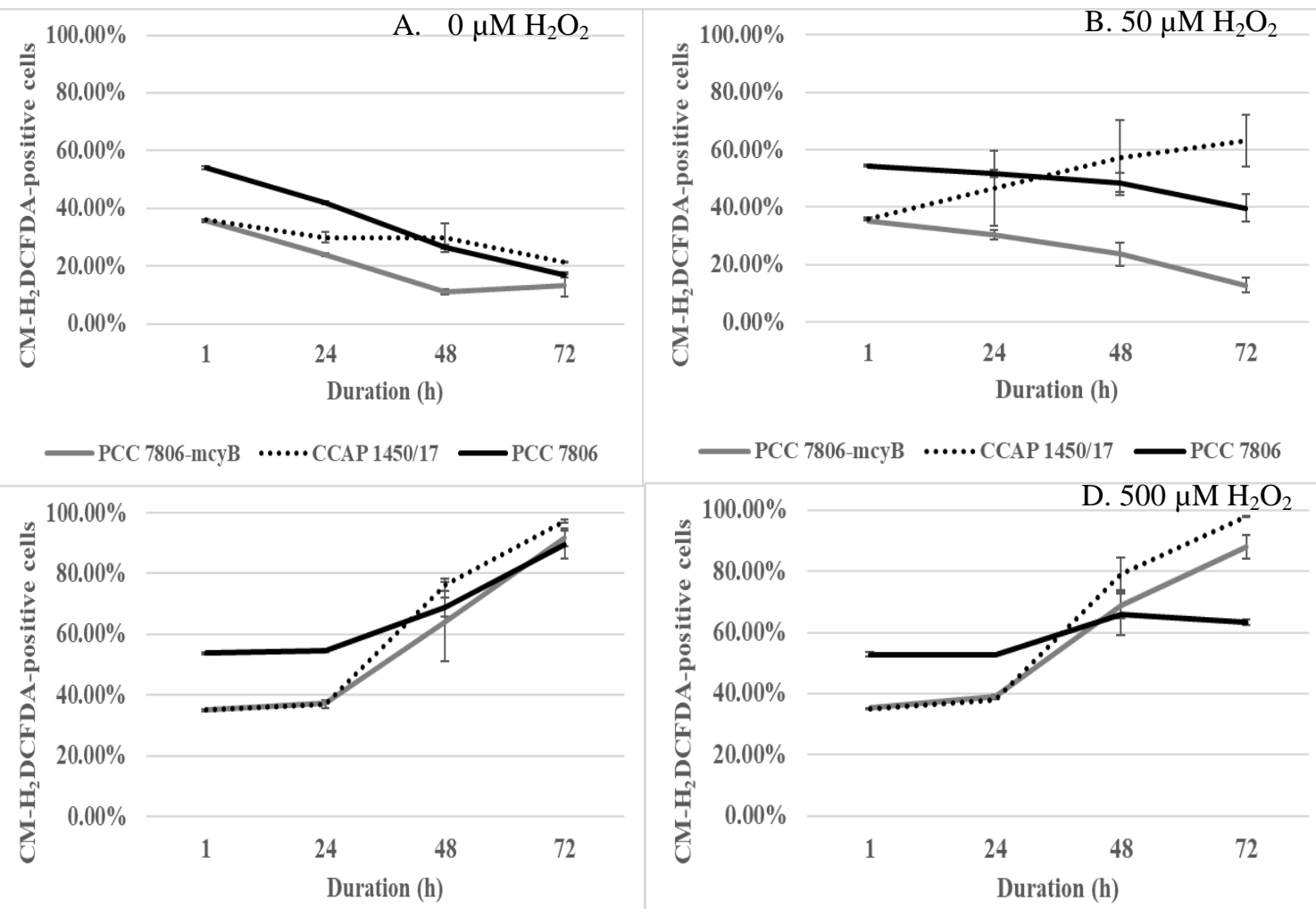

Fig. 2 CM-H2DCFDA (ROS) positive cells (\%) produced in three Microcystis strains in untreated (A) and $\mathrm{H}_{2} \mathrm{O}_{2}$ treated (B): $50 \mu \mathrm{M}$; (C): $275 \mu \mathrm{M}$; (D): $500 \mu \mathrm{M}$ ) cells; over time. Values are given as the means \pm standard deviation (SD) of three replicates 
490 Table 1 Influence of sub-lethal $\mathrm{H}_{2} \mathrm{O}_{2}(40 \mathrm{nM}-4000 \mathrm{nM})$ concentration on percentage dead cells in Microcystis strains

\begin{tabular}{|c|c|c|c|c|c|}
\hline \multirow[t]{2}{*}{ Strains } & \multirow{2}{*}{$\begin{array}{l}\mathrm{H}_{2} \mathrm{O}_{2} \text { dose } \\
\text { Incubation }\end{array}$} & \multicolumn{4}{|c|}{ Percentage dead cells (\%) } \\
\hline & & $0 \mathrm{nM}$ & $40 \mathrm{nM}$ & $400 \mathrm{nM}$ & $4000 \mathrm{nM}$ \\
\hline \multirow[t]{3}{*}{ PCC 7806- $m с y B$} & $24 \mathrm{~h}$ & $50.06 \pm 0.18^{\mathrm{a}}$ & $50.14^{\mathrm{a}}$ & $49.94^{\mathrm{a}}$ & $50.30^{\mathrm{a}}$ \\
\hline & $48 \mathrm{~h}$ & $43.32 \pm 0.20^{\mathrm{a}}$ & $42.82^{\mathrm{a}}$ & $42.52^{\mathrm{a}}$ & $41.98^{\mathrm{b}}$ \\
\hline & $72 \mathrm{~h}$ & $38.02 \pm 0.25^{\mathrm{a}}$ & $35.92^{\mathrm{b}}$ & $35.18^{\mathrm{b}}$ & $33.39^{\mathrm{b}}$ \\
\hline \multirow[t]{3}{*}{ CCAP 1450/17 } & $24 \mathrm{~h}$ & $25.92 \pm 0.66^{\mathrm{a}}$ & $25.32^{\mathrm{a}}$ & $26.84^{\mathrm{b}}$ & $26.53^{\mathrm{b}}$ \\
\hline & $48 \mathrm{~h}$ & $23.74 \pm 0.02^{\mathrm{a}}$ & $23.61_{b}$ & $24.02^{\mathrm{b}}$ & $23.39^{\mathrm{b}}$ \\
\hline & $72 \mathrm{~h}$ & $16.22 \pm 0.50^{\mathrm{a}}$ & $18.06^{\mathrm{b}}$ & $17.85^{\mathrm{b}}$ & $16.61^{\mathrm{a}}$ \\
\hline \multirow[t]{3}{*}{ PCC 7806} & $24 \mathrm{~h}$ & $12.92 \pm 0.01^{\mathrm{a}}$ & $12.67^{\mathrm{b}}$ & $12.52^{\mathrm{b}}$ & $12.92^{\mathrm{a}}$ \\
\hline & $48 \mathrm{~h}$ & $19.36 \pm 0.01^{\mathrm{a}}$ & $17.76^{\mathrm{b}}$ & $21.02^{\mathrm{b}}$ & $17.42^{\mathrm{b}}$ \\
\hline & $72 \mathrm{~h}$ & $14.43 \pm 0.02^{\mathrm{a}}$ & $12.92^{\mathrm{b}}$ & $14.64^{\mathrm{b}}$ & $14.42^{\mathrm{a}}$ \\
\hline
\end{tabular}

$491 \stackrel{\mathrm{a}-\mathrm{b}}{\mathrm{a}}$ : Different letters within the same row indicate significant difference relative to respective control $(p<0.05)$.

492

493 Table 2 Total microcystins and variants cellular quotas in the Microcystis strains analyzed by UHPLC and MS/MS

\begin{tabular}{lccc}
\hline Strains & MC-LR & {$\left[\right.$ Dha $\left.^{7}\right]-M C-L R$} & Total microcystins \\
& $($ fg/cell $)$ & Asp3-MC-LR (fg/cell) & $($ fg/cell $)$
\end{tabular}

\begin{tabular}{lcccccc} 
& \multicolumn{1}{c}{ Range } & Mean & Range & Mean & Range & Mean \\
PCC 7806 & $14.85-23.00$ & 18.60 & $5.20-10.80$ & 8.75 & $21.95-31.90$ & 27.40 \\
CCAP 1450/17 & $15.90-27.70$ & 21.55 & $7.10-13.80$ & 10.60 & $22.70-41.50$ & 32.15 \\
PCC 7806- $m c y B$ & nd & & nd & nd & >LOD
\end{tabular}

494 *LOD for MC-LR=0.0013 $\pm 0.0011 \mathrm{ng} / \mathrm{mL}$ and $\left[\mathrm{Dha}^{7}\right]-\mathrm{MC}-\mathrm{LR} / \mathrm{Asp} 3-\mathrm{MC}-\mathrm{LR}=0.002 \pm 0.0014 \mathrm{ng} / \mathrm{mL}(\mathrm{Turner}$ et $\mathrm{al}$ $495 \quad 2018$ )

496 

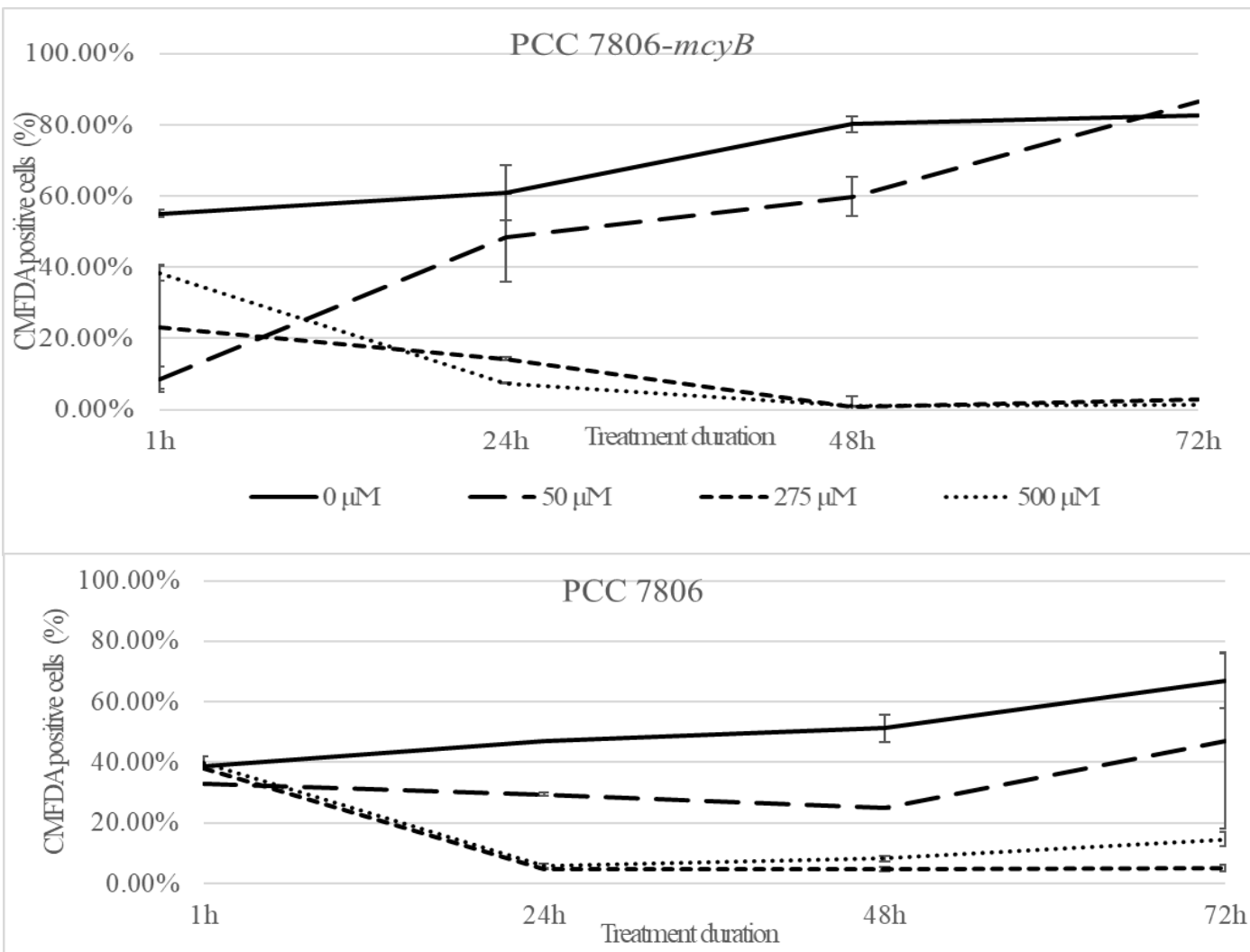

$\longrightarrow 0 \mu \mathrm{M} \quad-\quad-50 \mu \mathrm{M} \quad \mathbf{- - - 2} 275 \mu \mathrm{M} \quad$ ….. $500 \mu \mathrm{M}$

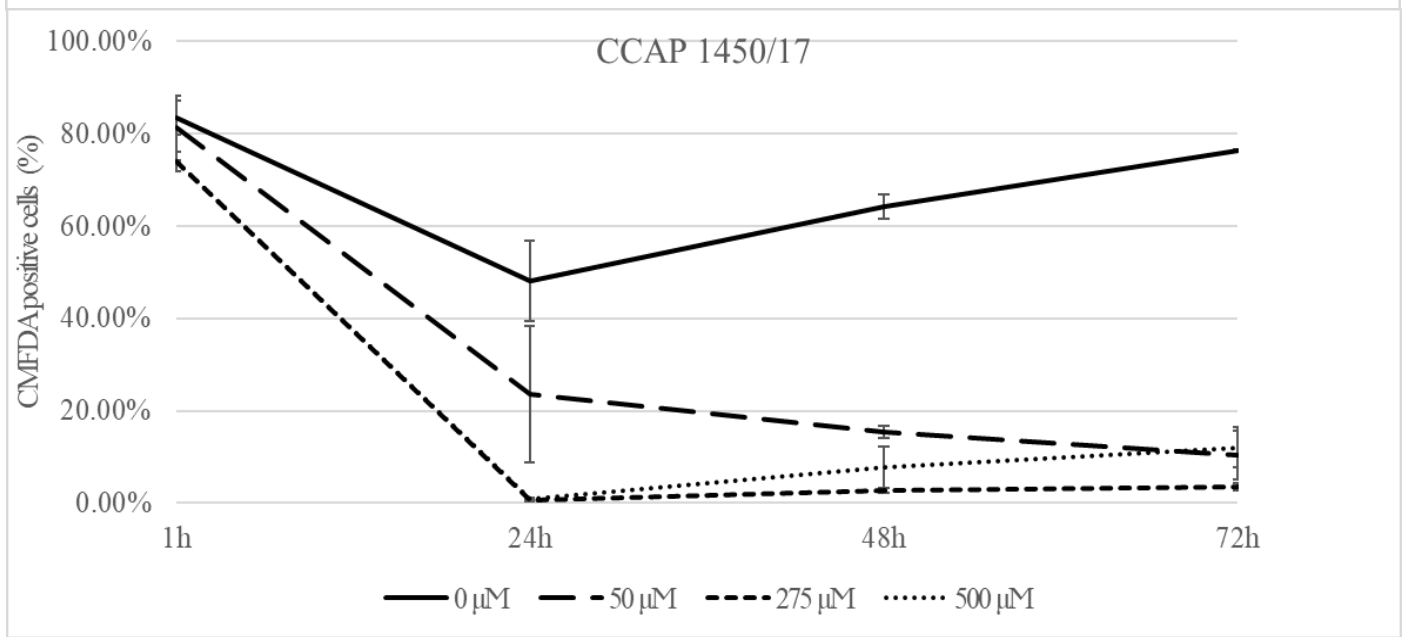

Fig. 3 Percentage cells showing esterase activity via CMFDA staining at increasing $\mathrm{H}_{2} \mathrm{O}_{2}$ treatment in three 503 Microcystis strains. Values are given as the means \pm standard deviation (SD) of three replicates 

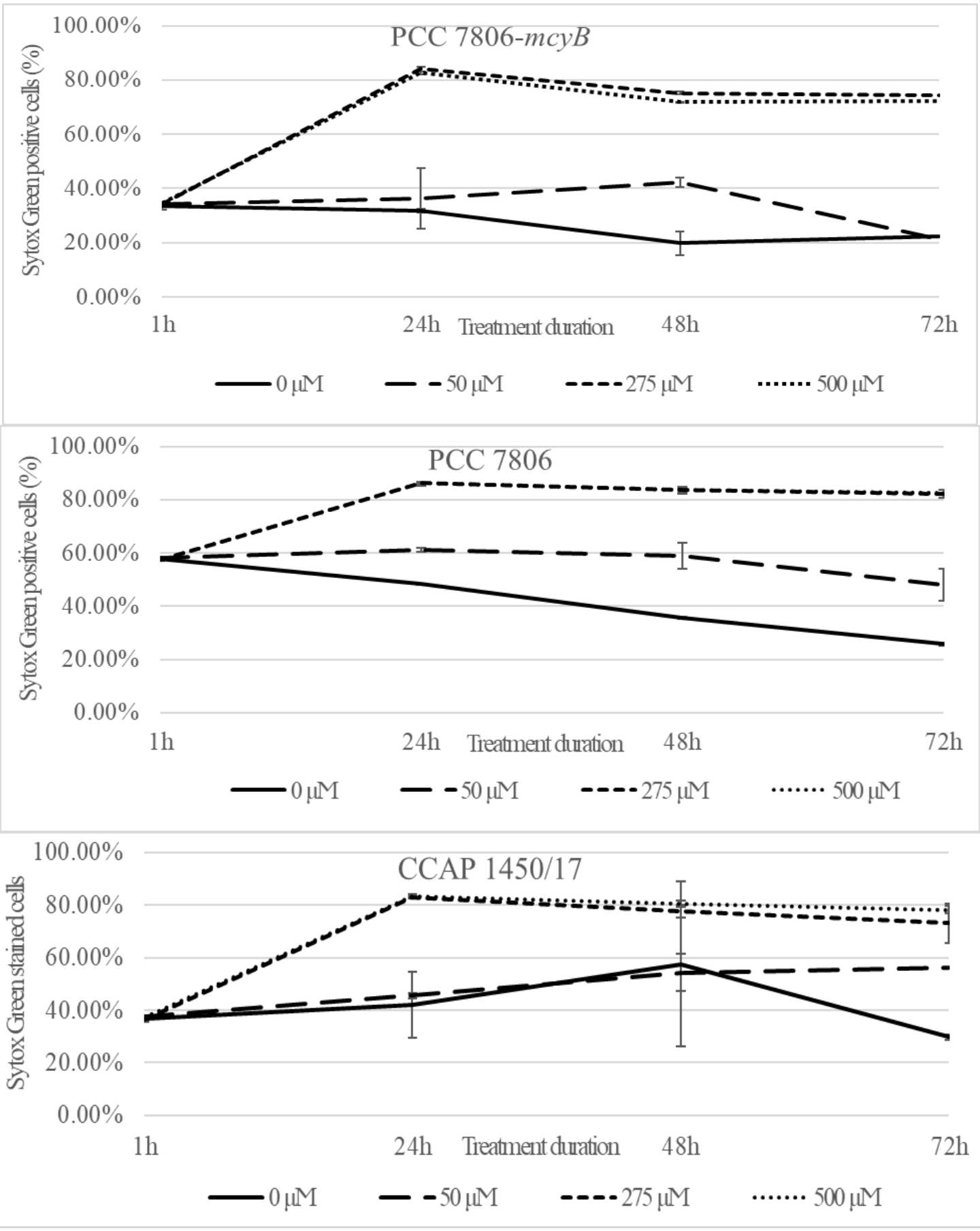

509 Fig. 4 Percentage dead cells via Sytox Green staining at increasing $\mathrm{H}_{2} \mathrm{O}_{2}$ treatment in three Microcystis strains. 510 Values are given as the means \pm standard deviation (SD) of three replicates 